D 201

\title{
流体現象とのインタラクティブ性を活用したメディア芸術の創出
}

\author{
荒川 忠一○ (東京大学), 鈴木 太朗(東京大学)
}

\section{Media Art Installation of Fluid Phenomena with Use of Interaction}

\author{
Chuichi ARAKAWA and Taro SUZUKI
}

\begin{abstract}
One of he authors who has developed the field of fluid dynamics, flow visualization and computational fluid dynamics becomes eager to establish the new idea and technology to combine its beauty of fluid motion with the interactive representation of media-art while cooperating with another author who is a young artist. The expression in this area is not confined to pure esthetics and personal interests. These new artistic expressions and installations are surely extended and developed to new industrial products in our society in near future.
\end{abstract}

Keywords: Visualization, Media Art, Interaction, Water Canvas, Liquid Sculpture

\section{1. 緒 論}

本研究の目的は、水や空気といった自然環境の運動力 学をアートの表現に利用することはいうまでもなく、そ こに高度なインタラクティブ性を導入し、人間と自然と の新たな感覚的交流の回路を切り拓くようなメディア技 術を確立することにある。メディア・アートの基盤技術 となるインターフェイスの研究開発を通して、これから 述べるインスタレーションにおいて、作品と㘕賞者を円 滑に結びつけるインタラクション環境を実現する。鑑賞 者自身が造形行為に直接参加し、作品の一部ともなりう るようなアートの創出を目ざし、そのための先進技術の 基盤を筑こうとするものである。

\section{Water Canvas with Ears $と$ Liquid Sculpture}

「Water Canvas with Ears」および「Liquid Sculpture」と題する作品は、多数の気泡の上昇運動を 利用して、水槽の中に自在に模様を描くインスタレーシ ヨンである。また、冰のドーム」にも示されているよう に、水や空気の特質を利用したアートは、それらの物理 現象そのものがもつ造形的な美が、鑑賞者に新鮮な警き や感動をもたらすだけでなく、ある種の癒しとも呼べる ような効果をも引き起こす。

申請者らが所属する東京大学情報学環と東京藝術大学
は、大学の枠を超えたコラボレーションによって、既に 2000年以来、「Water Canvas with Ears」(図 1) および 「Liquid Sculpture」(図 2) と題する作品を制作・発表 してきた。これらの作品は、多数の気泡の上昇運動を利 用して、水槽の中に自在に模様を描くインスタレーショ ンである。デジタル技術の導入によって、水と空気の泡 の運動を芸術表現に利用する可能性が大きく進展した。 風の動きや水の流れなど、自然現象のなかで起きる運動 をそのまま利用した従来のキネティック・アートとは異 なり、人間との対話、つまり鑑賞者自身の身体運動を入 力に結びつけたインタラクティブ性を備えることによっ て、人間をも含む環境情報を駆使した新しいメディア・ アートの可能性を示すことができたのである。

杉原有紀氏の作品で、既に巷間で高い評価を得ている 「水のドーム」(図 3) にも示されているように、水や空 気の特質を利用したアートは、それらの物理現象そのも のがもつ造形的な美が、鑑賞者に新鮮な驚きや感動をも たらすだけでなく、ある種の㾞しとも呼べるような効果 をも引き起こす。それは、シミュレーションやグラフィ ック技術によって、スクリーン上に単純に投影されたも のを見るときとはまた異なる知覚であり、おそらくは、 流体の運動が非線形性をもつがゆえに、単純な解析的関 数で示される数学的に整った形態となる代りに、「摇ら ぎ」をもった調和が自然に生み出されるためと考えられ る。 


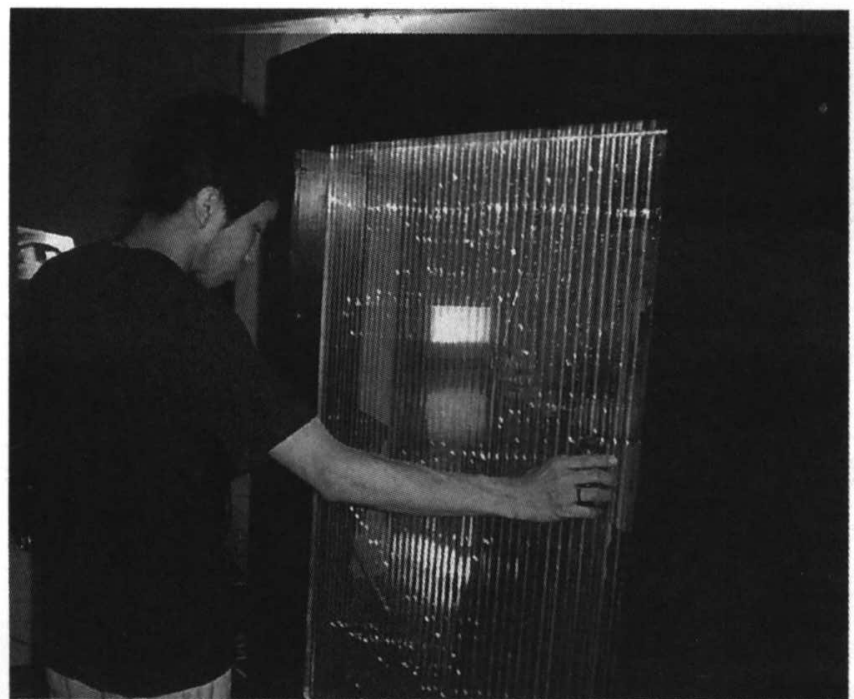

Fig.1 Water Canvas with Ears

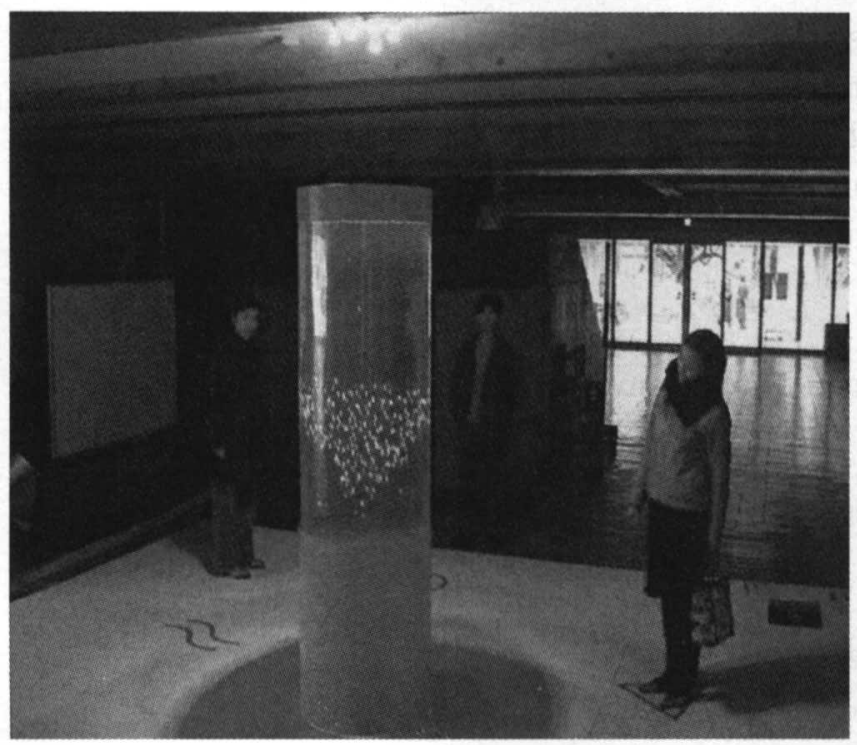

Fig.2 Liquid Sculpture

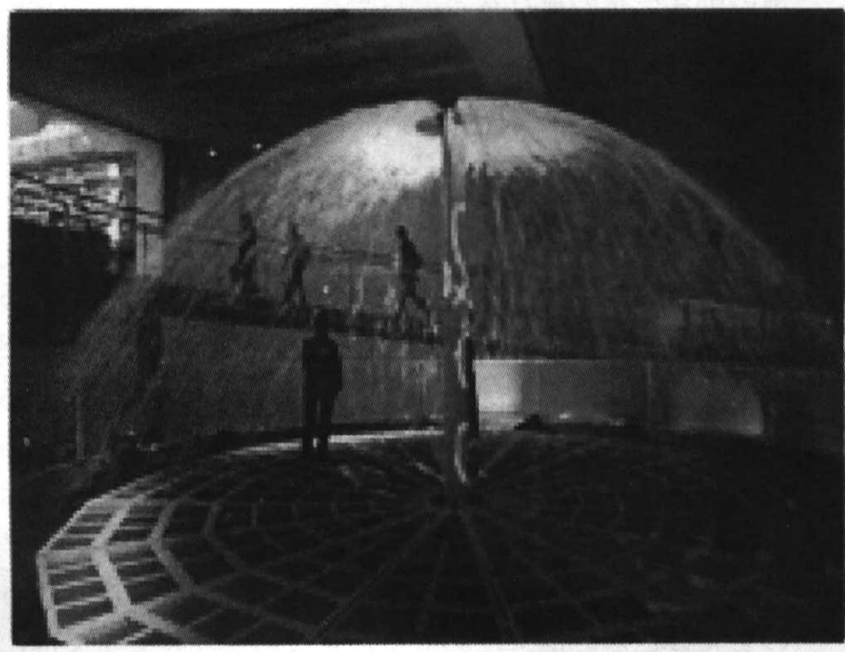

Fig.3 Dome of Water
「Water Canvas with Ears」で実現された、気泡の上昇 運動によるパターン形成を応用した装置は、現在、テレ ビ番組の背景として応用され始めている。また、米国の 芸術家グループが、噴水の動きを利用した大規模なイン スタレーションを、一種のアトラクションとしてテー マ・パークなどに導入しつつある。とはいえ、これらの 作品は、あくまで流体の運動それ自体の美しさを示すこ とを目標に据えており、申請者らが提唱してきたような インタラクティブ性については配慮がなされていない。 本研究は、上述したような作品制作を通して探究を重ね てきた、自然現象における流体運動と人間とのインタラ クティブな関係を重視し、新しいメディア・アートの表 現方法を創出していこうとしている。

\section{3. 作品のインタラクティブ性}

本研究の特徵は、水や空気といった自然環境の運動力 学をアートの表現に利用することはいうまでもなく、そ こに高度なインタラクティブ性を導入し、人間と自然と の新たな感覚的交流の回路を切り拓くようなメディア技 術を確立しようと目指していることにある。

筆者らが手がけてきた「Water Canvas with Ears」は、 気泡を用いて水中に模様を描いていく、「水のキャンバ ス」とも呼ぶべき作品である。水中で上昇運動を行う気 泡の出力すなわち生成タイミングを、音の要素（音程） によってコントロールすることで、さまざまなフォルム が描き出される。具体的には、水を満たしたアクリル製 薄型水槽と、その底部に横一列に設置した48個の流量制 御バルブで構成されている（作品寸法は高さ $190 \mathrm{~cm} \times$ 横 幅 $190 \mathrm{~cm} \times$ 奥行き $24 \mathrm{~cm})$ 。これらのバルブへは、外部のエ アコンプレッサーからチューブを通して空気が送られ、 おのおののバルブのロから上昇する気泡が、ちょうど 1 つを1ドットとして、スクリーンに見たてた水槽のなかに 多様な図形や文字を描いていく。

鑑賞者が、一定の音程・音量を発するスピーカー付き デバイスを手に持ち、本体の前で左右に動かすと、移動 する音源に呼応して流量制御バルブの開く位置も移動す る。その結果、鑑賞者の手の動きが気泡の軌跡に反映さ れ、あたかも気泡による描画が行われているかのような 視覚的効果を生む。鑑賞者の身体動作が引き起こす、こ のようなインタラクティブな反応は、水と空気という自 然の素材を媒介として、身振りと視覚と聴覚とが共鳴し あう独特の感覚をもたらす。

「Liquid Sculpture」もまた、水中での気泡の動きとい う自然現象と音響とをメディアとして利用したもので、 コンピュータ制御、複数の音声スピーカー（図 4)、およ びセンサーシステムを用いることによって、インタラク ティブな機能を持たせた作品である。直径 $60 \mathrm{~cm}$ 、高さ $210 \mathrm{~cm}$ の大型円柱水槽内に、エアコンプレッサーから送 
られる空気が、水槽底面に格子状に設置された 249 個の噴 き出し口（図 5) から気泡として出力され、浮力に従っ て上方に移動する。その際、電磁バルブ（図6）の開閉 で気泡の出力するタイミングを制御することにより、三 次元の立体的な造形すなわち「水の彫刻」が、鑑賞者の 眼前に立ち現れる。鑑賞者の立つ位置は、当初は赤外線 センサーによって検知されていたが、現在では、上部に 設置したC C D カメラが捉えた画像を基にリアルタイム で演算され、この位置に応じて、気泡が描き出す模様の 選択が行われる。さらにまた、水槽の周囲には、合計 249 個のスピーカーを埋設した $5 \mathrm{~m} \times 5 \mathrm{~m}$ の上げ底床が設置 されており、これらのスピーカーからの音響出力は、前 述の気泡の動きおよび鑑賞者の位置と連動している。つ まり「水の彫刻」は、気泡を用いた三次元のディスプレ イ機能と、空間的な音響生成機能とを実装することによ り、鑑賞者の身体の動きが視覚情報（気泡）と聴覚情報 （音声出力）の双方へと遡及していく、包括的なインタ ラクティブ性を備えているのである。

以上のように、自然現象を素材として、鑑賞者と作品と のあいだに複数の感覚によるインタラクティブな関係を 構築しうるようなデジタル技術を開発していくことが、 本プロジェクトの最も独創的な点であり、メディア・ア 一トにおける表現の可能性を大きく広げるものとして、 今後さらに研究を加え、ひとつの確固たる先進技術とし て確立していくべきである。

国内の類似研究としては、既述のとおり、「水のキャン バス」をテレビのスタジオに導入する動きがある。とは いえこの研究グループは、気泡を利用した美しい表現の 追求に目標を据えており、メディア・アートを支える先 進技術の開発とは方向性を異にしている。また国外では、 米国・カリフォルニアの芸術家たちからなるベンチャー 会社 WET-Design が、噴水を中心としたインスタレーシ ヨン作品を制作し、日本を含む各国の公園施設などへの 普及を図っているが、それらにおいては、鑑賞者はいま だ受動的な位置にとどまっている。アートはもはや受身 で享受するだけのものではなく、鑑賞者が積極的に創造 に関与し、作品と新たな関係性を結んでいくべきという 議論が近年盛んに行われているなか、本研究においても また、水と空気という自然素材を媒体として、鑑賞者自 身が造形行為に直接参加し、作品の一部ともなりうるよ うなアートの創出を目ざした。

\section{4. 今後の方向性}

コンピュータやセンサーなどの技術の著しい革新に 伴い、鑑賞者からの入力に反応して作品自体が何らかの 出力を行うことで成立するインタラクティブなアート の領域は、近年めざましく発展しつつある。しかしなが ら、インタラクティブな機能を備えた作品の多くにおい ては、その重要な構成要素であるインターフェイスにつ

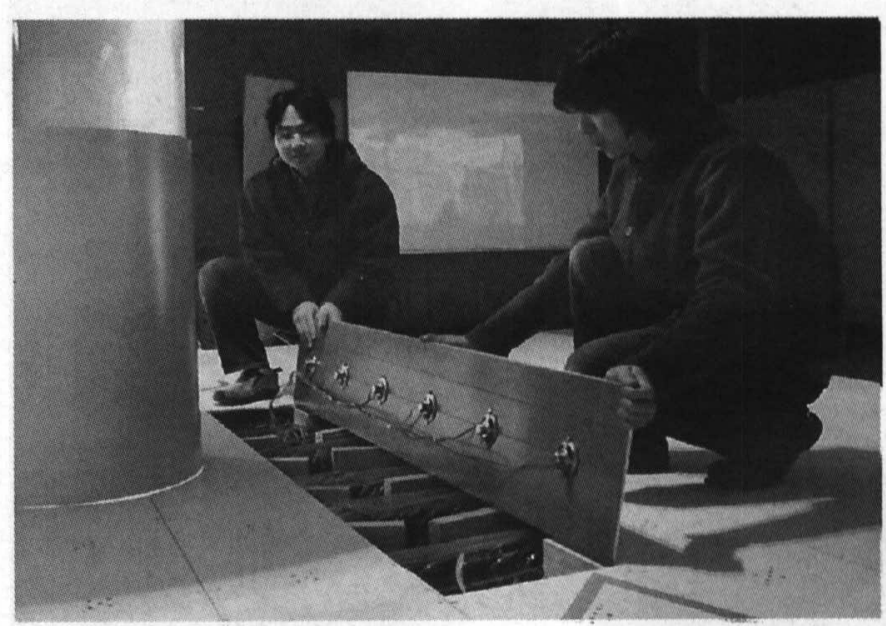

Fig.4 Speakers installed under the stage された

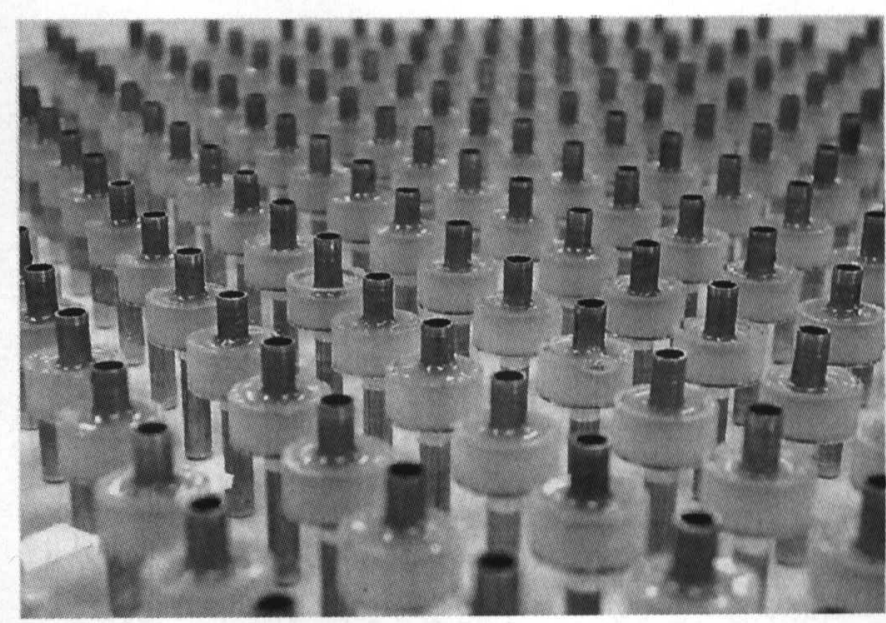

Fig.5 248 pieces of air nozzle

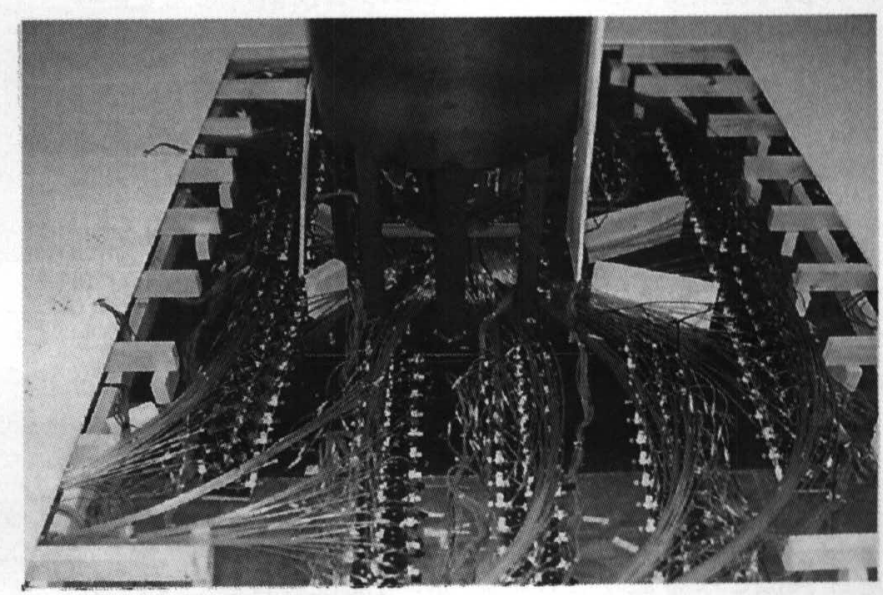

Fig.6 Installation of air-bubble control 


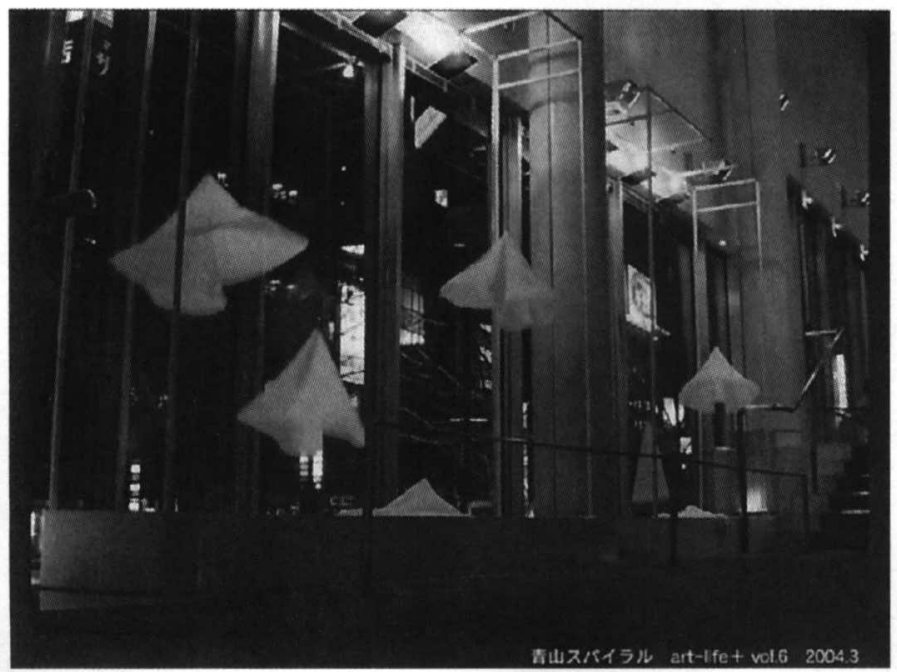

Fig.7 Artistic movement of fall with cloths

いては技術的に機能してはいるものの、芸術的な観点か ら見た場合、美的価值の高いものはまだまだ少ないのが 現状である。それは、技術と芸術の融合が、いまだ真の 意味で果たされていないためにほかならない。このよう な状況に対する解決策として、今後のインタラクティ ブ・アートには次の 3 つの要素が求められるだろう。

ひとつめは、技術的なものの存在を意識することなく、 観賞者が作品と自然に一体感を得ることができるよう なシステム構成の開発である。

ふたつめは、最新の技術を用いることによって初めて 成立するような、今までにない表現と鑑賞のありかたを 追求することであり、それによってアートそれ自体のパ ラダイムシフトをも目ざすことが可能となる。

三番目の要素は、新たな表現素材の活用や情報伝達の 方法を提案し、それに対応するような技術の開発を試み ることである。

メディア・アートの基盤技術となるインターフェイス の研究開発を通して、作品と鑑賞者を円滑に結びつける インタラクション環境を実現し、より質の高いインタラ クティブ・アートの制作への道筋をつけることが重要と 考えている。なかでも、創造的な情報伝達のための新し い素材として、自然環境のなかに存在する流体の運動と 音響という組み合わせに注目し、水や空気の動きと鑑賞 者の身体感覚とをインタラクティブに結び合わせるこ とによって、生命環境における水や空気の存在とその重 要性を直感的に理解し、人間の営みと環境との調和を促 す契機となるような芸術表現の可能性を目ざしている。

この一例として、これまで述べてきた気泡上昇運動に よる表現に加えて、自然現象における他の流体運動を利 用したインタラクティブ・アートの創造にも挑戦してい る。前出の「水のドーム」は、視覚的なアート作品とし て完成度の高いものであるが、さらにインタラクティブ 性の導入を図ることによって、表現の多様化と鑑賞者の
積極的な関与を目ざしていく。例えば、筆者の 1 名の 作品である、「布」が空中を舞い落ちる運きの効果にも 注目している（図 7)。これらの素材が持つ、自然現象 としての美しさを大切にしながら、鑑賞者とのインタラ クティブな関係を構築することにより、人間と自然をめ ぐるメディア・アートの新たな表現領域の拡大に向けて、 先進技術の研究開発を行うものとする。本研究において は、さまざまな分野の研究グループが、それぞれの専門 領域に関する情報を相互に提供しあい議論を重ねてい くことによって、技術と芸術の融合を図り、自然環境に おける流体運動と人間の営みとのハーモニーの創造に 貢献することができると確信している。

\section{5. 結語}

流体力学、可視化、数值流体力学の研究を遂行して きた研究者が、現在大きな興味をもっているのが、その 美しさを利用した新しい概念と技術の確立である。流体 力学の自然の美しさを、積極的に人間の感性と結びつけ るインタラクティブな表現は、単なる人間の美学的興味 に留まるものではない。新しい価值観を生み出し、人間 社会の中にひとつの製品として入り込むことを目指し て、その普及に努めていきたい。

\section{参 考 文 献}

筆者らのメディアアートとデザインの文献を紹介す る。

1. 荒川忠一, 松村誠一郎, “流体とメディアアートの融合と 発展…Liquid Sculpture を例にとって‥”, 第 81 期日本機 械学会流体工学部門講演会, 日本機械学会流体工学部門 講演会講演論文集, CD·ROM (2003), 大阪.

2. Chuichi Arakawa, Seiichi Ariga, Makoto Iida: "Proposal of Vernacular Design for Wind Turbine," Journal of Wind Engineering and Industrial Aerodynamics, 90, pp.1731·1741 (2002.4).

3. 松村誠一郎, 鈴木太朗, 荒川忠一, 伊藤隆道, “気泡と音 響を用いたインターラクティブアート”, 環境芸術学会論 文集, 第 2 号, (2002), pp.29-36.

4. 荒川忠一, 有賀誠一, 飯田誠, “ヴァナキュラー風車の提 案”, 環境芸術学会論文集, $1 \cdot 1,(2001), p p .13 \cdot 19$. 